\title{
Investigation of Entamoeba histolytica in stool specimens by direct microscopic examination and ELISA in a hospital
}

\section{Bir hastanede gaita örneklerinde direkt mikroskopik inceleme ve ELISA ile Entamoeba histolitika araştırılmast}

\author{
Türkan Toka Özer ${ }^{1}$, Erkan Yula ${ }^{1}$, Özcan Deveci ${ }^{2}$, Alicem Tekin ${ }^{3}$, Süleyman Durmaz ${ }^{4}$, \\ Keramettin Yanık ${ }^{5}$ \\ ${ }^{1}$ Kizultepe General Hospital, Department of Medical Microbiology, Mardin, Turkey \\ ${ }^{2}$ Kizlltepe General Hospital, Department of Infectious Diseases, Mardin, Turkey \\ ${ }^{3}$ Dicle University, Medical Faculty, Department of Medical Microbiology, Diyarbakır, Turkey \\ ${ }^{4}$ Erciyes University, Medical Faculty, Department of Medical Microbiology, Kayseri, Turkey \\ ${ }^{5}$ Amasya General Hospital, Department of Medical Microbiology, Amasya, Turkey \\ Geliş Tarihi / Received: 19.08.2011, Kabul Tarihi / Accepted: 30.08.2011
}

\begin{abstract}
Objectives: Stool antigen assay has been shown to be as sensitive and specific as culture with isoenzyme analysis and to outperform microscopy for the detection of E.histolytica in endemic area. The aim of the present study is to investigate the presence of E.histolytica by direct microscopic examination and ELISA in stool samples, comparatively.
\end{abstract}

Materials and methods: Between September 2010 and May 2011, a total of 975 stool samples of patients in different age groups were sent to microbiology laboratory of Kızıltepe General Hospital. Native-Lugol method and E.histolytica-specific antigen test (Adhesin Ag, Entamoeba CELISA Path) was applied to all stool samples.

Results: E.histolytica/dispar cysts and/or trophozoites were observed in 21 out of 975 (2.2\%) stool samples examined by native-Lugol method. In addition, E.histolyticaspecific antigen in 975 stool specimens was investigated by ELISA. E.histolytica-specific antigen was determined in 4 patients which had E.histolytica/dispar cysts and/or trophozoites at direct microscopic examination. Although at direct microscopy of 3 patients E.histolytica/dispar cysts and/or trophozoites not observed, E.histolyticaspecific antigen was found favorable. A total of $7(0.7 \%)$ E.histolytica specific antigen was found in the patient's stool samples. Patients with E.histolytica-specific antigen were treated.

Conclusion: E.histolytica specific antigen in stool samples should be investigated to avoid unnecessary treatment.

Key words: Entamoeba histolytica/dispar, specific antigen, ELISA, direct microscopic examination.

\section{ÖZET}

Amaç: Dışkı örneklerinde antijen testinin, izoenzim analizi ile birlikte kültür kadar duyarlı ve özgül bir test olduğu ve endemik bölgelerde mikroskopik bakıyı safdışı bıraktığı gösterilmiştir. Bu çalışmanın amacı; dışkı örneklerinde direkt mikroskopik bakı ve ELISA yöntemi ile Entamoeba histolytica varlığının araştırılmasıdır.

Gereç ve yöntem: Çalışmaya; Eylül 2010-Mayıs 2011 tarihleri arasında Kızıltepe Devlet Hastanesi Mikrobiyoloji laboratuvarına gönderilen, farklı yaş gruplarındaki hastalara ait 975 dışkı örneği dahil edildi. Tüm dışkı örneklerine nativ-Lugol yöntemi ve E.histolytica-özgül antijen testi (Adhesin Ag, Entamoeba CELISA Path) uygulandı.

Bulgular: Direkt bakıda nativ-Lugol yöntemi ile incelenen 975 dışkı örneğinin 21'inde (\%2.2) Entamoeba histolytical dispar kist ve/veya trofozoitleri görüldü. Ayrıca 975 dışkı örneğinde, ELISA yöntemi ile E.histolytica özgül antijeni araştırıldı. Direk mikroskopik bakıda Entamoeba histolytica/dispar kist ve/veya trofozoitleri görülen hastaların sadece 4'ünde E. histolytica özgül antijeninin varlığı tespit edildi. Fakat 3 hastanın direk mikroskopik bakısında Entamoeba histolytica/dispar kist ve/veya trofozoitleri görülmezken E.histolytica özgül antijeni ise pozitif bulundu. Toplam olarak 7 (\% 0.7) hastanın dışkı örneğinde E.histolytica özgül antijeninin varlığı tespit edildi. E.histolytica özgül antijeni saptanan olgulara uygun tedavi başlandı.

Sonuç: Hastaların gereksiz tedavi almasını önlemek için dışkı örneklerinde E.histolytica özgül antijeninin varlığı araştırılmalıdır.

Anahtar kelimeler: Entamoeba histolytica/dispar, özgül antijen, ELISA, direk mikroskopik bakı 


\section{INTRODUCTION}

Entamoeba histolytica is the causative agent of amoebiasis and is globally considered a leading parasitic cause of human mortality. Clinical features of amoebiasis due to E.histolytica range from asymptomatic colonization to amebic dysentery and invasive extraintestinal amoebiasis, which is manifested most commonly in the form of liver abscesses. Approximately 50 million people have invasive disease, resulting in 100,000 deaths per year. ${ }^{1}$ Although the parasite has a worldwide distribution, high prevalence rates of more than $10 \%$ of the population have been reported from various developing countries. ${ }^{2}$ Entamoeba dispar appears to be about 10 times more common than E.histolytica, with most of the 500 million people infected with E.histolytica/E.dispar carrying E.dispar. ${ }^{1}$

Entamoeba histolytica and Entamoeba dispar parasitize approximately $10 \%$ of the world population, of which $90 \%$ are asymptomatic infections. ${ }^{3}$ Infections of E.histolytica and E.dispar are often diagnosed by demonstrating cysts or trophozoites in a stool sample. A great number of methods for distinguishing E.histolytica from E.dispar have now been described in the literature. ${ }^{4}$ E.dispar and E.histolytica are morphologically indistinguishable from one another. Isoenzyme analysis is considered the "gold standard" for differentiating E.histolytica and E.dispar, but this method is not currently available and not readily usable for routine diagnosis. More recently, several studies have been devoted to the development of new techniques either based on monoclonal antibodies or molecular biology methods to successfully distinguish the two species in human feces. ${ }^{3}$ Stool antigen assay has been shown to be as sensitive and specific as culture with isoenzyme analysis and to outperform microscopy for the detection of E.histolytica in areas of endemicity. ${ }^{5}$

Reliable distinction would have a medical impact as until now, both infections are usually treated, whereas only approximately $10 \%$ (pathogenic infections) need to be treated. This proportion drops too much lower levels in developed countries, where E.histolytica infection is not endemic and occurs mostly after travelling to areas of endemicity. ${ }^{3}$

The present study was carried out to examine the prevalence and etiological agent of amoebiasis in Kiz1ltepe. The main aim of this study was to demonstrate the importance of correctly identifying E.histolytica in order to avoid unnecessary treatment costs and delayed treatment of actual infection.

\section{MATERIALS AND METHODS}

\section{Collection of stool samples}

Between September 2010 and May 2011, a total of 975 stool samples of patients of different age groups sent to Microbiology Laboratory of Kiziltepe General Hospital were included in present study.

\section{Microscopic examination}

Stool samples were investigated by native-Lugol examination. Lugol's iodine was added to the stool smear and covered with a cover slip. Stool smears with saline or iodine examined microscopically at low (10X) and high (40X) magnifications within 15 minutes.

The identification of E.histolytica/dispar trophozoites was made by the characteristic movement of the protozoan and the presence of phagocytized red blood cells. The identification of amebic cysts (E.histolytica/dispar) was based on morphologic characteristics, (10-15 $\mu \mathrm{m}$, spherical form, mature tetranucleated cysts having a central endosome).

\section{Entamoeba antigen test}

Following microscopic examination by nativeLugol method, all of stool specimens were investigated for Entamoeba histolytica/dispar screening by Micro-ELISA method using commercial kits (Adhesin Ag, Entamoeba CELISA Path) regarding with the existence of adhesin antigens.

\section{RESULTS}

E.histolytica/dispar cysts and/or trophozoites were observed in 21 out of 975 (2.2\%) stool samples examined by native-Lugol method. E.histolyticaspecific antigen in 975 stool specimens was investigated by ELISA. E.histolytica-specific antigen was determined in 4 patients which had E.histolytical dispar cysts and/or trophozoites at direct microscopic examination. Although at direct microscopy of 3 patients E.histolytica/dispar cysts and/or trophozoites not observed, E.histolytica-specific antigen was found favourable. A total of $7(0.7 \%)$ E.histolytica specific antigen was found in the patient's stool 
samples. Patients with E.histolytica-specific antigen had been treated.

\section{DISCUSSION}

Amoebiasis is defined as infection with Entamoeba histolytica, regardless of associated symptomatology. In resource-rich nations, this parasitic protozoan is seen primarily in travelers to and emigrants from endemic areas. Infections range from asymptomatic colonization to amebic colitis and life-threatening abscesses. Importantly, disease may occur months to years after exposure. Although E.histolytica was previously thought to infect $10 \%$ of the world's population, 2 morphologically identical but genetically distinct and apparently non-pathogenic Entamoeba species are now recognized as causing most asymptomatic cases. To avoid unnecessary and possibly harmful therapies, clinicians should follow the diagnostic and treatment guidelines of the World Health Organization. ${ }^{6}$

Entameoba histolytica, 1 of the 2 Entamoeba species with similar morphology that infect humans, causes invasive intestinal and extraintestinal diseases, whereas Entamoeba dispar is found commensally and is non-invasive. Because of their morphologic similarity, E.histolytica and E.dispar cannot be differentiated microscopically. The antigens of E.histolytica and E.dispar, however, may be detected by the ELISA method. Previous studies have found that the detection of antigens in the stool samples is as sensitive and specific as cultures and isoenzyme analyses. ${ }^{7}$

Studies were carried out at a mexican pediatric hospital to determine the ratio between the pathogenic species Entamoeba histolytica and non-pathogenic species E.dispar using an enzyme linked immunosorbent assay (ELISA) to detect the lectin (1 galactose $\mathrm{N}$-acetyl D-galactosamine) of E.histolytica in feces. A close correlation was noted between the presence of the E.histolytica lectin and clinical symptoms. In this study, amoebas were detected by microscopy in 120 children (either E.histolytica or E.dispar). But while almost all (13/14) of the children with E.histolytica had clinical symptoms, dysentery-feces with mocus and blood, diarrhea, cramping abdominal pain, tenesmus rectal, flatulence, vomiting and headache, almost none $(1 / 106)$ of the children infected with the non-pathogenic amoeba E.dispar had signs and symptoms. This suggests that much of the amoebiasis diagnoses made in Mexico are, in fact, due to non-pathogenic E.dispar. ${ }^{8}$

Malatyalı et al. ${ }^{9}$ reported that a total of 1449 stool samples were examined by native-Lugol and Trichrome staining, and 312 (22\%) samples were positive for one or more parasite species. Additionally, $22(1.5 \%)$ stool samples were found to be positive for the presence of E.histolytica/dispar cysts, and these samples were further examined by E.histolytica specific antigen based ELISA. As a result, ELISA test gave negative reactions for all the samples. Also, there was no cross reaction with other luminal protozoa such as Escherichia coli, Giardia intestinalis, Blastocystis hominis and Iodamoeba butschlii. The data reveals that E.histolytica prevalence may be lower than estimated.

A record is available that indicates that E.histolytica is more common than E.dispar in Zonguldak. Mengeloglu et al. ${ }^{10}$ reported that amebic cysts were observed in $44(0.37 \%)$ out of a total of 1720 stool specimens which were examined by direct microscopy. Entamoeba histolytica specific antigen was investigated with ELISA in the specimens that cysts were observed. Specific antigen was detected in $26(59.1 \%)$ of these specimens. Because of the low sensitivity of direct microscopy in confirming the prediagnosis of amoebiasis, it is necessary to perform ELISA on the specimens in order to determine whether the patient should be treated or to prevent patients from being given an unnecessary treatment.

Zeyrek et al. ${ }^{11}$ reported that a total of 87 stool specimens that were doubtful using the nativeLugol method were examined by the E.histolytica specific sensu-lato antigen based ELISA test and the Trichrome staining method. Of these 87 stool specimens, $23(26.4 \%)$ specimens were positive for E.histolytica/E.dispar trophozoites/cysts microscopically using Trichrome staining and 19 (21.7\%) of the stool specimens were found to be positive for the E.histolytica/E.dispar complex by the ELISA test.

Tuncay et al. ${ }^{12}$ reported that stool samples of 9378 patients from different clinics, with several gastrointestinal complaints from January 2004 to May 2006, were examined. All stool samples were examined with the native-Lugol method and, in suspicious cases, by Trichrome staining, cultivation 
in Robinson's medium and/or antigen detection in stool with the Entamoeba CELISA Path kit. Fortyone cases (0.44\%), in which Entamoeba histolytical Entamoeba dispar cysts and/or trophozoites were detected by at least one method, were found to be positive.

In the world, the prevalence of E.histolytica is around $10 \%$ on average, but reaches up to $50 \%$ or $80 \%$ have been reported, in some regions. In Turkey the prevalence of E.histolytica is reported 0 to $17 \%$. However, there are studies reporting high rates of detected between 43.2 to $77.7 \%{ }^{10}$

In the light of earlier reports about the prevalence of amoebiasis in such subjects, interpretation is very difficult because older data did not differentiate between morphologically identical species, one that is non-invasive (E.dispar) and are that is invasive (E.histolytica), but they have a high degree of divergence. It is very important to keep in mind that according to the older data, many E.histolytica infections were most probably confused with E.dispar due to limited data obtained from microscopic examinations. ${ }^{13}$

In conclusion, our findings are consistent with those previously reported studies in Turkey. Direct microscopic diagnosis of amoebiasis is not an efficient method for the diagnosis of E. histolytica, so we recommend stool antigen detection tests today offer a practical, sensitive, and specific method for the clinical laboratory to detect intestinal E.histolytica.

\section{REFERENCES}

1. Fotedar R, Stark D, Beebe N, Marriott D, Ellis J, Harkness J. Laboratory diagnostic techniques for Entamoeba species. Clin Microbiol Rev 2007;20(3):511-32.
2. Stanley SL. Amoebiasis. Lancet 2003;361:1025-34.

3. Gonin P, Trudel L. Detection and differentiation of Entamoeba histolytica and Entamoeba dispar isolates in clinical samples by PCR and enzyme-linked immunosorbent assay. J Clin Microbiol 2003;41(1):237-41.

4. Nesbitt RA, Mosha FW, Katki HA, Ashraf M, Assenga C, Lee CM. Amebiasis and comparison of microscopy to ELISA technique in detection of Entamoeba histolytica and Entamoeba dispar. J Natl Med Assoc 2004;96(5):671-7.

5. Pillai DR, Keystone JS, Sheppard DC, MacLean JD, MacPherson DW, Kain KC. Entamoeba histolytica and Entamoeba dispar: epidemiology and comparison of diagnostic methods in a setting of nonendemicity. Clin Infect Dis 1999;29(5):1315-8.

6. Pritt BS, Clark CG. Amebiasis. Mayo Clinic Proceedings 2008;83(10):1154-60.

7. Delialioglu N, Aslan G, Ozturk C, Ozturhan H, Sen S, Emekdas G. Detection of Entamoeba histolytica antigen in stool samples in Mersin, Turkey. J Parasitol 2008;94(2):530-2.

8. Redondo RB, Martinez Mendez LG, Baer G. Entamoeba histolytica and Entamoeba dispar: differentiation by Enzyme-Linked Immunosorbet Assay (ELISA) and its clinical correlation in pediatrics patients. Parasitol Latinoam 2006;61:37-42.

9. Malatyalı E, Özçelik S, Çeliksöz A. The investigation of Entamoeba histolytica Prevalance in some villages of Sivas by ELISA method. Turkiye Parazitol Derg 2011;35:6-9.

10. Mengeloglu FZ, Aktas E, Kulah C, Comert Begendik F. Detection of Entamoeba histolytica in stool specimens with the ELISA Method. Türkiye Parazitol Derg 2009;33(1):1-3.

11. Yildiz Zeyrek F, Ozbilge H, Yüksel MF, Zeyrek CD, Sirmatel F. Parasitic fauna and the frequency of Entamoeba histolytica/Entamoeba dispar detected by ELISA in stool samples in Sanliurfa, Turkey. Türkiye Parazitol Derg 2006;30(2):95-8.

12. Tuncay S, Inceboz T, Over L, et al. The evaluation of the techniques used for diagnosis of Entamoeba histolytica in stool specimens. Turkiye Parazitol Derg 2007;31(3):18893.

13. Tanyuksel M, Petri WA. Laboratory Diagnosis of Amoebiasis. Clin Microbiol Rev 2003;16(4):713-29. 